\title{
CAMBRIDGE
}

\section{Language Acquisition}

\section{edited by Paul Fletcher and Michael Garman}

Thirty-two specially commissioned articles based on research by specialists in various aspects of the field offer a comprehensive account of a child's first language development from infancy to about nine years. $\quad \$ 59.50 / \$ 14.95$

\section{A Functional Approach to Child Language}

\section{A Study of Determiners and References}

\section{Annette Karmiloff-Smith}

"Karmiloff-Smith's exhaustive study of determiner usage in a large sample of French-speaking children from 3 to 12 years of age shows that language learning is itself a central field of development and problem-solving, which reacts back upon the thinking process in ways consonant with the familiar Piagetian developmental sequence."-Choice. Cambridge Studies in Linguistics 24

\section{The Organization of Language Janice Moulton and George M. Robinson}

"The book is provocative and contains a great many interesting and clever features. The comments on transformational generative grammar alone are worth the price of admission.... a fine contribution."-David McNeill, Professor of Behavioral Sciences, University of Chicago forthcoming

\section{Sociolinguistics}

\section{R. A. Hudson}

Hudson provides a theoretical framework within which the findings of sociolinguistics may be related to a theory of linguistic structure. Cambridge Textbooks in Linguistics

$\$ 37.50 / \$ 10.95$

Learning to Talk by John McShane

Studies in the Acquisition of Deictic Terms by Christine Tanz (Cambridge Studies in Linguistics 26)

Social Markers in Speech edited by Klaus R. Scherer \& Howard Giles

(European Studies in Social Psychology, co-published with

Les Editions de la Maison des Sciences de l'Homme)

Talking to Children: Language Input and Acquisition

edited by Catherine Snow \& Charles Ferguson

Before Speech: The Beginnings of Interpersonal Communication edited by Margaret Bullowa

Metaphor and Thought edited by Andrew Ortony

Thinking: Readings in Cognitive Science

edited by P. N. Johnson-Laird \& P. C. Wason

Expression and Meaning: Studies in the Theory of Speech Acts by John R. Searle 


\section{The Behavioral and Brain Sciences}

An International Journal of Current Research and Theory with Open Peer Commentary

\section{ISSN 0140-525X}

Editor

Stevan Harnad

\section{Assistant Editor}

Helaine Randerson

\section{Associate Editors}

Animal Intelligence

David Premack

University of Pennsylvania

Behavioral Biology

Jack P. Hailman

University of Wisconsin

Cognition and Artificial Intelligence

Zenon Pylyshyn

University of Western Ontario

Developmental Psychology

Charles J. Brainerd

University of Western Ontario

Ethology and Neuroethology

John C. Fentress

Dalhousie University

Evolutionary Biology

Michael T. Chiselin

University of Utah

Experimental Analysis of Behavior

A. Charles Catania

University of Maryland Baltimore County

Higher CNS Function

Robert W. Doty

University of Rochester

\section{Volume 31980}

Cambridge University Press

Cambridge

London New York New Rochelle

Melbourne Sydney

1980

\author{
History and Systems \\ Julian Jaynes \\ Princeton University \\ Language and Cognition \\ Peter Wason \\ University College London \\ Neurobiology \\ Graham Hoyle \\ University of Oregon \\ Neurophysiology \\ Barry H. Smith \\ National Institutes of Health \\ Neuropsychology \\ Karl Pribram \\ Stanford University \\ Philosophy \\ Daniel C. Dennett \\ Tufts University \\ Psychobiology \\ David S. Olton \\ Johns Hopkins University
}


Published by the Press Syndicate of the University of Cambridge

The Pitt Building, Trumpington Street, Cambridge CB2 1RP

32 East 57th Street, New York, NY 10022

296 Beaconsfield Parade, Middle Park, Melbourne 3206

(c) Cambridge University Press 1980

Printed in the United States of America by Science Press, Ephrata, Pennsylvania 


\section{Contents Volume 31980}

\section{Number 1, March 1980}

\section{Target Article}

Chomsky, N. Rules and representations

\section{Open Peer Commentary}

Andor, J. Some remarks on the notion of competence

Cromer, R. F. Empirical evidence in support of nonempiricist theories of mind

Cummins, R. and Harnish, R. M. The language faculty and the interpretation of linguistics

Dennett, D. C. Passing the buck to biology

Ghiselin, M. T. Evolutionary anatomy and language

Gottlieb, G. Elaboration of maturational and experiential contributions to the development of rules and representations

Harman, G. Two quibbles about analyticity and psychological reality

Hudson, P. T. W. Minimalism in cognition and language: rich man, poor man

Lakoff, G. What ever happened to deep structure?

Marshall, J. C. The new organology

Matthews, R. J. Language learning versus grammar growth

McCawley, J. D. „Tabula si, rasa no!
Moravcsik, J. M. Chomsky's radical break with modern traditions

Morton, A. There are many modular theories of mind

Morton, J. Language: levels of characterisation

Rachlin, H. Cross purposes

Rollin, B. E. Innate and a priori

Rosenthal, D. M. The modularity and maturation of cognitive capacities

Sampson, G. Chomsky's evidence against Chomsky's theory

Schank, R. C. An artificial intelligence perspective on Chomsky's view of language

Searle, J. R. Rules and causation

Sober, E. Representation and psychological reality

Stich, S. P. What every speaker cognizes

Van Gulick, R. Knowledge and learning

Author's Response

Chomsky, N. The new organology

28

29

29

\section{Target Article}

\section{Fodor, J. A. Methodological solipsism considered as a research strategy in} cognitive psychology

\section{Open Peer Commentary}

Block, N. and Bromberger, S. States' rights

Charniak, E. Some aspirin for Dasein

Churchland, P. M. In defense of naturalism

Cohen, L. J. Some defects in Fodor's 'computational' theory

Cummins, R. Causes and representation

Davis, L. On the need for a computational psychology and the hope for a naturalistic one

Dreyfus, H. L. Dasein's revenge: methodological solipsism as an unsuccessful escape strategy in psychology

Evans, G. Fodor flawed

Geach, P. T. Some remarks on representations

Harman, G. What is methodological solipsism?

Haugeland, J. Formality and naturalism

Hayes, P. Knowing about formality

Isard, S. D. Sensing and reference

Joshi, A. K. The content of a representation also depends on the procedure interpreting it

Jusczyk, P. W. and Earhard, B. Implications of Fodor's methodological solipsism for psychological theories
Katz, J. J. Fodor's guide to cognitive psychology

Loar, B. F. Syntax, functional semantics, and referential semantics

Norman, D. A. Fodor's solipsisms: don't look a gift horse in the ...

Rey, G. The formal and the opaque

Rosenthal, D. M. Methodological behaviorism: a case for transparent taxonomy

Searle, J. R. Two objections to methodological solipsism

Shaw, R. and Turvey, M. T. Methodological realism

Smart, J. J. C. Computational processes, representations and propositional attitudes

Stich, S. P. Paying the price for methodological solipsism

Woodfield, A. Methodological solipsism

\section{Authors' Response}

Fodor, J. A. Methodological solipsism: replies to commentators 


\section{Target Article}

\section{Pylyshyn, Z. W. Computation and cognition: issues in the foundations of cognitive science}

\section{Open Peer Commentary}

Churchland, P. S. Neuroscience and psychology: should the labor be divided?

Churchland, P. M. Plasticity: conceptual and neuronal

Colby, K. M. From computational metaphor to consensual algorithms

Demopoulos, W. A remark on the completeness of the computational model of mind

Fortescue, M. In defence of the armchair

Grossberg, S. Human and computer rules and representations are not equivalent

Haugeland, J. Psychology and computational architecture

Heil, J. Computation, cognition, and representation

Hulse, S. H. The reification of the mind-body problem?

Hunt, E. The borders of cognition

Keil, F. Reductionism and cognitive flexibility

Klatzky, R. L. The elusive visual processing mode: implications of the architecture/algorithm distinction

Kyburg, H. E., Jr. Functional architecture and free will
Miller, G. A. Computation, consciousness and cognition

Miller, J. R. Cognitive penetrability: let us not forget about memory

Moore, R. C. Criteria of cognitive impenetrability

134 Pinker, S. Explanations in theories of language and of imagery

135 Powers, W. T. Pylyshyn and perception

135 Rey, G. Penetrating the impenetrable

Ringel, M. Functional architecture and model validation

Smythe, W. E. Computation and symbolization

138 Stich, S. P. Computation without representation

139 Weimer, W. B. Cognition is not computation, for the reasons that computers don't solve the mind-body problems

Zucker, S. W. Functional architectures for cognition: are simple inferences possible?

\section{Author's Response}

Pylyshyn, Z. W. Cognitive representation and the process-architecture distinction

\section{Number 2, June 1980}

\section{Target Article}

\section{Symons, D. Précis: The evolution of human sexuality}

\section{Open Peer Commentary}

Alcock, J. Beyond the sociobiology of sexuality: predictive hypotheses

Bernstein, I. S. Motives, intentions, science, and sex Dewsbury, D. A. Methods in the two sociobiologies

Diamond, M. The biosocial evolution of human sexuality

Eysenck, H. J. Sociobiology - standing on one leg

Geis, G. and Huston, T. L. Forcible rape and human sexuality

Ghiselin, M. T. Is sex sufficient?

Hailman, J. P. Fitness, function, fidelity, fornication, and feminine philandering

Heiman, J. R. Selecting for a sociobiological fit

Hoffman, M. R. An interactionist perspective on human sexuality

King, G. E. Pair bonding and proximal mechanisms

Lamb, M. E. On the origins and implications of sex differences in human sexuality

Lancaster, J. B. and Lancaster, C. S. The division of labor and the evolution of human sexuality

McGrew, W. C. The proper study of sociobiological mankind is sex

McGuinness, D. Male and female choice in human sexuality
Mitchell, G. Sex differences and intent

Ridley, M. Konrad Lorenz and Humpty Dumpty: some ethology for Donald Symons

Ruse, M. Is science sexist?

Sade, D. S. Human sexuality: hints for an alternative explanation

sexuality

186 Tennov, D. The clarification of proximate

187 mechanisms

Tompkins, L. An (im) printed circuit theory of sexual behavior

Udry, J. R. Female sexual adaptability: a consequence of the absence of natural selection among females

191 Weitz, S. Sex differences in sexuality: what is their relevance to sex roles?

192 Whalen, R. E. Evolutionary causation: how proximate is ultimate?

\section{Author's Response}

Symons, D. The evolution of human sexuality revisited 


\section{Target Article}

McGlone, J. Sex differences in human brain asymmetry: a critical survey

\section{Open Peer Commentary}

Annett, M. Sex differences in lateralitymeaningfulness versus reliability

Beatty, W. W. Sex differences in brain asymmetry: are there rodent models?

Bener, A. Sex differences: asymmetry in dermatoglyphics and brain

Blinkov, S. Sex differences, asymmetry, and variability

Bradshaw, J. L. Sex and side: a double dichotomy interacts

Bryden, M. P. Sex differences in brain organization: different brains or different strategies?

Butler, S. Sex differences in electrophysiological correlates of asymmetric cerebral function

Denenberg, V. H. Some principles for interpreting laterality differences

Diamond, M. C. New data supporting cortical asymmetry differences in males and females

Dimond, S. J. Sex differences in brain organization

Fairweather, H. Sex differences: still being dressed in the emperor's new clothes

Flor-Henry, P. Evolutionary and clinical aspects of lateralized sex differences

Glick, S. D., Schonfeld, A. R., and Strumpf, A. J. Sex differences in brain asymmetry of the rodent

Harris, L. J. Lateralized sex differences: substrates and significance

Hier, D. B. and Kaplan, J. Are sex differences in cerebral organization clinically significant?

Hoyenga, K. B. The puzzle of a sexually dimorphic brain

Ingle, D. Animal models for lateralized sex differences

Kimura, D. Sex differences in intrahemispheric organization of speech
Kinsbourne, M. If sex differences in brain lateralization exist, they have yet to be discovered

Lansdell, H. Man's skewed brain: factors and interests

LeMay, M. Sex differences in human brain morphology

Martin, L. J. Inadequate criteria for hypothesis testing in cerebral asymmetry research

McGee, M. G. The effect of brain asymmetry on cognitive functions depends upon what ability, for which sex, at what point in development

McGuinness, D. Strategies, demands, and lateralized sex differences

Morgan, M. J. Influences of sex on variation in human brain asymmetry

Nottebohm, F A continuum of sexes bedevils the search for sexual differences?

Ray, W. J. and Newcombe, N. Interpreting sex differences in lateralization

Rebert, C. S. Sex differences in complex visuomotor coordination

Sasanuma, S. Do Japanese show sex differences in brain asymmetry? Supplementary findings

Sherman, J. Sex-related differences in functional human brain asymmetry: verbal function - no; spatial function - maybe

Vandenberg, S. G. Age effects in neurometrics

Waber, D. P. What is the significance of sex differences in performance asymmetries?

Wolff, P. H. A difference that may make no difference

Author's Response

McGlone, J. Sex differences in brain asymmetry survive peer commentary!

\section{Target Article}

\section{deCatanzaro, D. Human suicide: a biological perspective}

\section{Open Peer Commentary}

Anisman, H. Depression and suicide: stress as a precipitating factor

Blanchard, D. C. Biological variation and suicide

Carr, E. G. Suicide: comments on deCatanzaro's diathesis-stress model

Dawkins, R. Domesticity, senescence, and suicide

Douglas, J. D. Baechler's theory of suicide

Duke, M. P. Feasting on the sociobiology of suicide: somehow I still feel hungry...

Farber, M. L. Suicide as natural selection

Frieden, G. Self-destructive behavior: suicide, shocks and worms

Hamilton, W. J. Do nonhuman animals commit suicide?

Hankoff, L. D. and Turner, W. J. A nontheory of suicide
Harmatz, M. G. The biological perspective on suicide to be or not to be - is that sociobiology?

Wenz, F. V. Heredity, environment, and culture in suicide perspective

Wilson, D. S. Suicide, beanbag genetics, and pleiotropy

\section{Author's Response}

deCatanzaro, D. Human suicide: toward a diathesisstress hypothesis 


\section{Target Article}

Bolles, R. C. and Fanselow, M. S. A perceptual-defensive-recuperative model of fear and pain

\section{Open Peer Commentary}

Adams, D. B. Motivational systems: fear or defense? pain or recuperation?

Appley, M. H. Stress and arousal in pain perception

Bindra, D. How are defensive and recuperative actions produced?

Blanchard, D. C. and Blanchard, R. J. PDR theory - a psychological approach to biological questions

Bowsher, D. Dual mechanism of pain

Catania, A. C. The explanation of motivation and the motivation of explanation

Chapman, C. R. and Gagliardi, G. J. Clinical implications of Bolles \& Fanselow's pain/fear model

Dubner, R. Naloxone produces a fear and pain model

Eichelman, B. Fear and pain: semantic, biochemical and clinical reflections

Eysenck, H. J. Fear, pain, and arousal

Fields, H. L. Pain is sufficient to activate the endorphin-mediated analgesia system

Fonberg, E. Pain and fear are different motivations

Gray, J. A. On the difference between pain and fear

301

301

Greenberg, G. Premature theorizing is not always parsimonious

Hayes, R. L. The multiplicity of physiological and behavioral variables modulating pain responses

Hendersen, R. W. Motivation and function

acquet, Y. F. B-endorphin and ACTH: inhibitory and excitatory neurohormones of pain and fear?

Melzack, R. Pain theory: exceptions to the rule

Miczek, K. A. The neurochemistry of defensive behavior and fear

Vierck, C. J. and Cooper, B. Y. Contextual determinants of pain reactions

Yaksh, T. L. Role of the intrinsic modulatory systems in somesthesis

\section{Authors' Response}

Bolles, R. C. and Fanselow, M. S. PDR - a multi-level model of fear and pain

\section{Number 3, September 1980}

\section{Target Article}

\section{Jensen, A. R. Précis of Bias in mental testing}

\section{Open Peer Commentary}

Brace, C. L. Social bias in mental testing

Breland, H. M. Population validity and admissions decisions

Brody, N. and Brody, E. B. Differential construct validity

Cattell, R. B. "They talk of some strict testing of us Pish"

Clarke, A. M. Unbiased tests and biased people

Dorfman, D. D. Test bias: What did Yale, Harvard, Rolls-Royce, and a black have in common in 1917?

Eckberg, D. L. The problem of hierarchial thought in the work of Arthur Jensen

Eckland, B. K. Competent teachers and competent students

Economos, J. Bias cuts deeper than scores

Gordon, R. A. Implications of valid (and stubborn) IQ differences: An unstatesmanlike view

Green, D. R. Achievement test bias

Harrington, G. M. Criteria of test bias: do the statistical models fit reality?

Havender, W. R. Individual versus collective social justice

Hirsch, J., Beeman, M. and Tully, T.P. Compensatory education has succeeded

Humphreys, L. G. Intelligence testing: the importance of a difference should be evaluated independently of its causes
Kempthorne, 0. and Wolins, L. Controversies surrounding mental testing

Kline, P. Test bias and problems in cross-cultural testing

Longstreth, L. E. The definitive work on mental test bias

Osborne, R. T. The Spearman-Jensen hypothesis

Reynolds, C. R. In support of Bias in Mental Testing and scientific inquiry

Rosenthal, R. Error and bias in the selection of data

Sternberg, R. J. Intelligence and test bias: Art and science

Tyler, L. E. Tests are not to blame

Vandenberg, S. G. An existence proof for intelligence?

Vernon P. E. Antitest views are refuted

Vetta, A. Correlation, regression and biased science

Vogel, F. Genetic influence on IQ

Wahlsten, D. Race, the heritability of $I Q$, and the intellectual scale of nature

\section{Author's Response}

Jensen, A. R. Correcting the bias against mental testing: A preponderance of peer agreement 
Mackworth, A. K. Are mediating representations the

\section{Open Peer Commentary}

Braddick, O. J. Direct perception: an opponent and a precursor of computational theories

Bridgeman, B. Direct perception and a call for primary perception

Doner, J. F. and Lappin, J. S. The function and process of perception

Epstein, W. Direct perception or mediated perception: a comparison of rival viewpoints

Grossberg, S. Direct perception or adaptive resonance?

$\mathrm{Gyr}, \mathrm{J}$. W. Visual perception is underdetermined by stimulation

Hayes-Roth, F. Mediating the so-called immediate processes of perception

Hinton, G. E. Inferring the meaning of direct perception

Johansson, G., von Hofsten, C. and Jansson, G. Direct perception and perceptual processes

Jones, R. K. and Pick, A. D. On the nature of information in behalf of direct perception

Keyser, S. J. and Pinker, S. Direct vs. representational views of cognition: A parallel between vision and phonology

Koenderink, J. J. Why argue about direct perception?

Loftus, G. R. and Loftus, E. F. Visual perception: the shifting domain of discourse perception
Mace, W. M. Perceptual activity and direct ghosts in the machine?

Prazdny, K. How wrong is Gibson?

393

394

Prindle, S. S., Carello, C., and Turvey, M. T. Animalenvironment mutuality and direct perception

Reed, E. S. Information pickup is the activity of perceiving

Rock, I. Difficulties with a direct theory of perception

Runeson, S. There is more to psychological meaningfulness than computation and representation

Shaw, R. and Todd, J. Abstract machine theory and direct perception

Sloman, A. What kind of indirect process is visual perception?

von Fieandt, K. In defense of invariances and higherorder stimuli

Weimer, W. B. Logical atomism and computation do not refute Gibson

Welker, W. Percepts, intervening variables, and neural mechanisms

Zucker, S. W. The computational/representational paradigm as normal science: further support

Zuckerman, C. B. What are the contributions of the direct perception approach?

Authors' Response

Ullman, S. Perception, information, and computation

397
Minsky, M. Decentralized minds

Puccetti, R. The chess room: further demythologizing of strong $A I$

Block, N. What intuitions about homunculi don't show

Danto, A. C. The use and mention of terms and the simulation of linguistic understanding

Pylyshyn, Z. W. The "causal power" of machines

Rachlin, H. The behaviorist reply (Stony Brook)

Dennett, D. The milk of human intentionality

Eccles, J. C. A dualist-interactionist perspective

Fodor, J. A. Searle on what only brains can do

Haugeland, J. Programs, causal powers, and intentionality

Hofstadter, D. R. Reductionism and religion

Libet, B. Mental phenomena and behavior

Lycan, W. G. The functionalist reply (Ohio State)

McCarthy, J. Beliefs, machines, and theories

Marshall, J. C. Artificial intelligence-the real thing?

Maxwell, G. Intentionality: Hardware, not software

Menzel, E. W. Is the pen mightier than the computer? intelligence

Rorty, R. Searle and the special powers of the brain

Schank, R. C. Understanding Searle

Sloman, A. and Croucher, M. How to turn an information processor into an understander

Smythe, W. E. Simulation games

Walter, D. O. The thermostat and the philosophy professor

Wilensky, R. Computers, cognition and philosophy

\section{Author's Response}

Searle, J. Intrinsic intentionality
Ringle, M. Mysticism as a philosophy of artificial

\section{Continuing Commentary on}

\section{Eysenck, H. J. (1979) The conditioning model of neurosis. BBS 2(2):155-99.}

Ellis, A. Some cognitive additions to Eysenck's "The conditioning model of neurosis"

Freides, D. Atavisms in psychopathological theory

Kondas, O. Human learning is more complex and fears are more influenced by ontogeny

Pinkava, V. A multivalued logical net modelling conditioning

459

460

461

461
Pitman, R. K. The conditioning model of neurosis: promise and limitations 
Toates, F. M. (1979) Homeostasis and drinking. BBS 2(1):95-136.

Bourbon, W. T. Anticipatory regulation: a raincoat does not feedforward make

465

466
Author's Response

Toates, F. M. The modelling of incentive motivation processes
Sinclair, J. D. Compensatory behaviors and the "rest principle"

466

Rosenthal, R. and Rubin, D. B. (1978) Interpersonal expectancy effects: the first 345 studies. BBS 1(3):377-415.

Clarke, A. M. The interpersonal approach to expectancy effects: the experimenter and the subjects

Darley, J. M. Interpersonal expectancy effects: $a$ future research agenda

Masling, J. On statistical stability and significance

Peeters, G. Social-cognitive factors in expectancy effects: why apples and oranges are fruits

Rosenberg, M. J. Experimenter expectancy, evaluation apprehension, and the diffusion of methodological angst

Corballis, M gst

472
Snyder, C. R. Applying the self-fullfilling prophecy: some thoughts on how the prophet forms and sustains expectations

\section{Authors' Response}

Rosenthal, R. and Rubin, D. B. Further issues in summarizing 345 studies of interpersonal expectancy effects laterality: I. Evidence for a maturational left-right gradient and II. The mechanisms of inheritance. BBS 1(2):261-336.

Hiscock, M. \& Kinsbourne, M. Is there a maturational left-right gradient for brain functions?

Rife, D. C. Laterality differences in twins

von $\mathrm{Kraft}, \mathrm{A}$. On the problem of the origin of asymmetric organs and human laterality

\section{Authors' Response}

Corballis, M. C. Human laterality: the other cheek Morgan, M. J. On the problem of the origin of asymmetric organs and human laterality: a reply to von Kraft

\section{Number 4, December 1980}

\section{Target Article}

Lynch, J. C. The functional organization of posterior parietal association cortex

\section{Open Peer Commentary}

Bisiach, E. The compass of the parietal "command" system

Butter, C. M. Posterior parietal cortex: Unity or independence of functions?

Chow, K. L. Inner structure of cortical columns

Deuel, R. K. The parietal association fields and behavior

Eidelberg, E. Is the parietal lobe guilty of association?

Ettlinger, G. How can we resolve the enigma of parietal cortex?

Glickstein, M. Postcrior parietal cortex and visual control of the hand

Goldberg, M. E. and Robinson, D. L. The significance of enhanced visual responses in posterior parietal cortex

499

500

500

501

501

502

503

503

Heilman, K. M., Watson, R. T., Valenstein, E., and Bowers, D. Neglect in man: Hemispheric asymmetries and hemispatial neglect

Hyvärinen, J. Sensorimotor interaction in parietal association cortext

Jones, E. G. Parietal cortex: Columns, connectivity, and convergence
Latto, R. Problems in comparing the behavioural effects of parietal cortex lesions in man and monkey and of integrating these with electrophysiological data

Mansfield, R. J. W. Global and local processing in the primate brain

Mesulam, M-M. An anatomical basis for the functional specialization of the parietal lobe in directed attention

Pandya, D. N. and Seltzer, B. Cortical connections and the functional organization of posterior parietal cortex

Roland, P. E. The posterior parietal association cortex in man

Rolls, E. T., Perrett, D. and Thorpe, S. J. The influence of motivation on the responses of neurons in the posterior parietal association cortex

Sakata, H. Reappraisal of the corollary discharge hypothesis

Schlag, J. Are parietal saccade neurons sensory or motor? Is the question worth asking?

Stein, J. A command or association function for the posterior parietal cortex? 
Thomas, R. K. Attention, motivation and emotion:

Entia non sunt multiplicanda praeter necessitatem

Troost, B. T. Clinical disorders of ocular motor control

Weinstein, E. A. Clinical features of hemi-

inattention

Mountcastle, V. B., Motter, B. C. and Andersen, R. A.
Some further observations on the functional properties of neurons in the parietal lobe of the waking monkey

\section{Author's Response}

Lynch, J. C. Parietal function: Different aspects of the unified whole

\section{Target Article}

\section{Selverston, A. I. Are central pattern generators understandable?}

\section{Open Peer Commentary}

Ayers, J. Do different behaviors require different central pattern generators?

Block, G. D. Snake oil and the modeling process in neurobiology

Calabrese, R. L. Invertebrate central pattern generators: modeling and complexity

Cohen, A. H. A new generation of experimental and theoretical methods is needed in neurobiology

Davis, W. J. Neurophilosophical reflections on central nervous pattern generators

Delcomyn, F. Even "simple" systems are more complex than we think

Fentress, J. C. Bursting networks

Friesen, W. O. Models, modeling, and the leech swimming rhythm

Gerstein, G. L. Models and multineuron recordings

Getting, P. A. Central pattern generators can be understood

Gillette, R. Adaptive significance, redundancy, and variance in central patterns generators

Goldberg, L. J. The failure of current strategies in the study of central pattern generators

Grillner, S. Can mammalian pattern generators be understood?

Harth, E. Must neural mechanisms be Newtonian?

Hartline, D. K. Roles for models in understanding neural networks

Hoyle, G. Expectation and achievement in analysis of motor program generation

Huber, F. Central pattern generators (CPGs) from the viewpoint of a behavioral physiologist

Kaneko, C. R. S. A practical approach to understanding central pattern generators

Larimer, J. L. and Thompson, W. Pessimism, models, and episodic behavior
Lent, C. M. On neuronal nihilism

Loeb, G. E. and Marks, W. B. Epistemology and heuristics in neural network research

Luco, J. V. Central pattern generators and sensory input

Merickel, M. Single-cell versus network properties and the use of models

Moffett, S. The comparative approach to understanding central pattern generators

Pentreath, V. W. At what level will pattern generators be understood?

Pinsker, H. M. Neuroethological analysis of central pattern generators

Reingold, S. C. and Gelperin, A. Central pattern generators and neuroethology

Rowell H. F. Philosophy leads to pessimism, research to understanding

Székely, G. Particulars and principles of nervous activity

Weeks, J. C. The implications of recent experimental results for the validity of modeling studies of the leech swim central pattern generator

Wendler, G. On the history and value of the central pattern generator concept

Wiens, T. J. Graded transmission, mechanistic multiplicity, and modeling

Willows, A. O. D. Central pattern generator analysis is alive and well

\section{Author's Response}

Selverston, A. I. Toward understanding central pattern generators

\section{Target Article}

\section{Sternberg, R. J. Sketch of a componential subtheory of human intelligence}

\section{Open Peer Commentary}

Berry, J. W. Cultural universality of any theory of human intelligence remains an open question

Borkowski, J. G. On the nature and measurement of metacomponents

Brody, N. Components to the rescue

Butterfield, E. C. On Sternberg's translation of $\mathrm{g}$ into metacomponents and on questions of parsimony

Carroll, J. B. Components and factors: Complementary "units" of analysis?

Collins, A. A cognitive scientist's view of intelligence

Detterman, D. K. Understand cognitive components before postulating metacomponents
Frederiksen, J. R. A Thurstonian's reaction to a

componential theory of intelligence

Guilford, J. P. Components versus factors

Hunt, E. The language of componential analysis

Keating, D. P. Sternberg's sketchy theory: Defining details desired 
Kline, P. Factors or processes in intelligence

Lansdell, H. Intelligence: Toward a modern sketch of $a$ good $\mathrm{g}$

MacLeod, C. M. Discovering and training the components of intelligence

Pellegrino, J. W. Three perspectives on intelligence
Royce, J. R. On theory and metatheory, and normal and revolutionary science

\section{Author's Response}

Sternberg, R. J. Claims, counterclaims, and components: A countercritique of componential analysis

\section{Continuing Commentary}

Premack, D. and Woodruff, G. (1978) Does the chimpanzee have a theory of mind? BBS 1:515-26.

Griffin, D. R. (1978) Prospects for a cognitive ethology. BBS 1:527-38.

Savage-Rumbaugh, E.S., Rumbaugh, D.M., and Boysen, S. (1978) Linguistically mediated tool use and exchange by chimpanzees (Pan troglodytes). BBS 1:539-

\section{4 .}

Lindauer, M. Cognition and consciousness - their evolutionary gradients

Schwartz, R. How rich a theory of mind?

Shanon, B. The significance of self-awareness

\section{Authors' Responses}

615 Griffin, D. R. What do animals think?

616 Savage-Rumbaugh, S., Scanlon, J. L., and Rumbaugh, D. M. Communicative intentionality in the chimpanzee
618

Eibl-Eibesfeldt, I. (1979) Human ethology: concepts and implications for the sciences of man. BBS 2:1-57.

Bekoff, M. Human ethology, biological determinism, directive genes, and trees

Bubenik, A. B. On demographic factors and neurohormonal substrates

Harrington, G. M. Locus of causation: analysis of ethological similarities

Markl, H. S. How much can the ethological approach contribute to an understanding of human behavior?

Pitman, R. K. Austro-German ethology and schizophrenia

Sapolsky, R. and Eichenbaum, H. Still-life

623

624

625

626

627 photographs: The power of human ethology in the explanation of human behavior

Simons, R. C. Eibl-Eibesfeldt's human ethology: The problem of evidence

Wassermann, G. D. A critique of some aspects of human ethology

Author's Response

Eibl-Eibesfeldt, I. Jumping on the sociobiology bandwagon 


\section{The Behavioral and Brain Sciences}

Call for papers (and topics, authors, nominations and suggestions)

Reader Reply Card (No postage necessary if mailed in the U.S. Others please affix air mail postage.)

I recommend the following topics/authors for target articles (or multiple book review treatment):

I recommend the following qualified scientist(s) or scholar(s) as BBS Associates (please include affiliations):

\section{Subscription Order Form - U.S. and Canada}

Please enter my subscription to Volume 4 (1981) of The Behavioral and Brain Sciences:

Institution $\$ \mathbf{8 9 . 0 0}$

$\square$ Individual $\mathbf{\$ 4 4 . 5 0}$ I hereby certify that this subscription is for my personal use only. (Individuals must order direct from the Press and pay by personal check or credit card.)

Student \$29.00 Proof of current student status must accompany order.

Please send information on BBS to my colleagues (please give full names and addresses).

Subscription rates apply through December 31, 1981.

\section{Subscription Order Form - U.K. and rest of world}

Please enter my subscription to Volume 4 (1981) of The Behavioral and Brain Sciences:

Institution $\mathbf{8 4 8 . 0 0}$

$\square$ Individual $£ \mathbf{2 4 . 0 0}$ I hereby certify that this subscription is for my personal use only. (Individuals must order direct from the Press and include payment with order.)

$\square$ Please send information on BBS to my colleagues (please give full names and addresses).
BBS would welcome your suggestions for optimizing the Open Peer Commentary service (e.g., number, length, format, quantity, quality, diversity and readability of commentaries and articles; selection and refereeing procedures for commentaries or articles, etc.):

\begin{tabular}{ll}
\hline Name & Field \\
\hline
\end{tabular}

\section{Address}

City

Payment enclosed. (Payment may be made in U.S. dollars or equivalent in Canadian dollars.)

VISABBankAmericard $\square$ Master Charge (Interbank no.

Card no. Expires

Signature

No postage necessary if mailed in the U.S.

Cambridge University Press, 32 East 57th Street, New York, NY 10022

Please send this card to any bookseller or subscription agent or direct to Cambridge University Press, P.O. Box 110, Cambridge CB2 3RL, England. Orders sent to the Press should be accompanied by payment, which may be made in sterling, by cheque, U.K. Postal Order, international money order, bank transfer (Barclays Bank Ltd, Bene't Street, Cambridge CB2 3PZ Code No.: 20/17/19 a/c no 70205931) or by Post Office Giro (a/c no 571 6055). If payment is made by Money Order, bank transfer or Giro, a separate advice should be sent to the Press. Cheques should be made payable to Cambridge University press.

$\square$ Payment enclosed $f$

Payment by BARCLAYCARD (U.K. only) No.

Amount $f$ Date 


\section{BUSINESS REPLY CARD \\ FIRST CLASS \\ PERMIT NO. 5206 \\ NEW YORK, NY}

POSIAGE WILL BE PAID BY ADDRESSEE

The Editor

The Behavioral and Brain Sciences

CAMBRIDGE UNIVERSITY PRESS

32 East 57 th Street

New York, N.Y. 10022

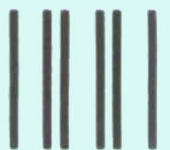

\section{BUSINESS REPLY CARD FIRST CLASS PERMIT NO. 5206 NEW YORK, NY}

POSTAGE WILL BE PAID BY ADDRESSEE

\section{CAMBRIDGE UNIVERSITY PRESS}

32 East 57 th Street

New York, N.Y. 10022 


\section{TheBehavioral and Brain Sciences}

\section{Instructions to Authors and Commentators}

THE BEHAVIORAL. AND BRAIN SCIENCES (BBS) is a unique scientific communication medium, providing the service of Open Peer Commentary for reports of significant current work in any area of psychology, neuroscience. behavioral biology or cognitive science. If a submitted manuscript is judged by BBS referees and editors to be appropriate for Commentary (see Criteria below), it is then circulated to a large number of commentators selected (with the aid of systematic bibliographic searches) from the BBS Associateship* and the worldwide biobehavioral science community, including individuals recom mended by the author

Once the Commentary stage of the process has begun. the author can no longer alter his article but he can respond formally to all commentaries accepted for publication. The target article, commentaries and author response then co-appear in BBS. Continuing Commentary and replies can appear in later issues

\section{Criteria for acceptance}

To be eligible for publication, a paper should not only meet the standards of a journal such as Psychological Review or the International Review of Neurobio. logy in terms of conceptual rigor, empirical grounding, and clarity of style but it should also offer a clear rationale for soliciting Commentary. That rationale should be provided in the author's covering letter. together with a list of suggested commentators. The original manuscript plus eight copies must be submitted

A paper for BBS can be (1) the report and discussion of empirical research that the author judges to have broader scope and implications than might be more appropriately reported in a specialty journal. (2) an unusually significant theoretical article that formally models or systematizes a body of research; or (3) a novel interpretation, synthesis, or critique of existing experimental or theoretical work. Occasionally, articles dealing with social or philosophical aspects of the behavioral and brain sciences will be considered

The service of Open Peer Commentary will be primarily devoted to original unpublished manuscripts. However, a recently published book whose contents meet the standards outlined above is also eligible for Commentary if the author submits a comprehensive, article-length précis to be published together with the commentaries and his response. In special cases, Commentary will also be extended to a position paper or an already published article dealing with particularly influential or controversial research Submission of an article implies that it has not been published or is not being considered for publication elsewhere Authors submitting previously published articles for consideration should give full information of place of publication, date, and include permission from the copyright holder to reprint The Associateship and professional readership of BBS are encouraged to nominate current topics and authors for Commentary.

In all the categories described, the decisive consideration for eligibility will be the desirability of Commentary for the contents of the submitted material. Controversiality simpliciter is not a sifficient criterion for soliciting Commentary a paper may be controversial simply because it is wrong or weak Nor is the mere presence of interdisciplinary aspects sufficient general cybernetic and "organismic" disquisitions are not appropriate for BBS Some appropriate rationales for seeking Open Peer Commentary would be that

- the material bears in a significant way on some current controversial issues in behavioral and brain science.

- its findings substantively contradict some well-established aspects of current research and theory.

- it criticizes the findings, practices, or principles of an accepted or influential line of work

- it unifies a substantial amount of disparate research

- it has important cross-disciplinary ramifications.

- it introduces an innovative methodology or formalism for consideration by proponents of the established forms

- it significantly integrates a body of brain and behavioral data

- it places a hitherto dissociated area of research into an evolutionary or ecological perspective; etc

In order to assure communication with potential commentators (and readers) from other BBS specialty areas. all technical terminology must be clearly defined or simplified, and specialized concepts must be fully described.

\section{Note to commentators}

The purpose of the Open Peer Commentary service is to provide a concentrated constructive interaction between author and commentators on a topic judged to

"Qualified professionals in the behavioral and brain sciences who have either (1) been nominated by a current BBS Associate, (2) refereed for BBS, or (3) had a commentary or article accepted for publication can become BBS Associates. Editors of learned journals and officers of scientific societies are invited to become BBS Associates ex officio for liaison purposes. Please write to the Editor for further information be of broad significance to the biobehavioral science community. Commentators should provide substantive criticism, interpretation, and elaboration as well as any pertinent complementary or supplementary material, such as illustrations; all original data will be refereed in order to assure the archival validity of BBS commentaries. Commentaries and articles should be free of hyperbole and remarks ad hominem

\section{Style and format for articles and commentaries}

Articles must not exceed 14,000 words (and should ordinarily be considerablv shorter); commentaries should not exceed 1,000 words. Spelling. capitalization, and punctuation should be consistent within each article and commentary and should follow the style recommended in the latest edition of A Manual of Style. The University of Chicago Press. It may be helpful to examine a recent issue of BBS A title should be given for each article and commentary. An auxiliary short title of 50 or fewer characters should be given for any article whose title exceeds that length. Each commentary must have a distinctive, representative commentary title. The contributor's name should be given in the form preferred for publication; the affiliation should include the full institutional address. Two abstracts, one of 100 and one of 250 words, should be submitted with every article. The shorter abstract will appear one issue in advance of the article; the longer one will be circulated to potential commenta. tors and will appear with the printed article. A list of 5-10 keywords should precede the text of the article. Tables and figures (i e photographs, graphs, charts, or other artwork) should be numbered consecutively in a separate series. Every table and figure should have a title or caption and at least one reference in the text to indicate its appropriate location. Notes, acknowledgements. appendixes, and references should be grouped at the end of the article or commentary Bibliographic citations in the text must include the author's last name and the date of publication and mav include page references. Complete bibliographic information for each citation should be included in the list of references. Examples of correct style for bibliographic citations are: Brown (1973); (Brown 1973); (Brown 1973; 1978); (Brown 1973, Jones 1976); (Brown \& Jones 1978); (Brown, Jones \& Smith 1979) and subsequently. (Brown et al 1979). References should be typed in alphabetical order in the style of the following examples

Kupferman, I \& Weiss, K (1978) The command neuron concept. The Behavioral and Brain Sciences 1:3-39

Dunn, J (1976) How far do early differences in mother-child relations affect later developments? In: Growing points in ethology. ed. P. P. G, Bateson \& R. A. Hinde, pp. 1-10. Cambridge: Cambridge University Press

Bateson, P. P. G \& Hinde, R. A, eds. (1976) Growing points in ethology

Cambridge: Cambridge University Press.

Journal titles should not be abbreviated.

\section{Preparation of the manuscript}

The entire manuscript, including notes and references, must be typed double spaced on $8 \frac{1}{2}$ by 11 inch or A4 paper, with margins set to accommodat approximately 70 characters per line and 25 lines per page, and should not exceed 50 pages. Pages should be numbered consecutively. It will be necessary to return manuscripts for retyping if they do not conform to this standard

Each table and figure should be submitted on a separate page, not interspersed with the text. Tables should be typed to conform to BBS style Figures should be ready for photographic reproduction; they cannot be redrawn by the printer Charts, graphs, or other artwork should be done in black ink on white paper and should be drawn to occupy a standard area of $81 / 2$ by 11 or $8 \frac{1}{2}$ by $5 \frac{1}{2}$ inches before reduction. Photographs should be glossy black-and-white prints. 8 by 10 inch enlargements are preferred. All labels and details on figures should be clearly printed and large enough to remain legible even after a reduction to half size. It is recommended that labels be done in transfer type of a sans-serif face such as Helvetica

Authors are requested to submit their original manuscript with eight copies for refereeing, and commentators their original plus two copies, to Stevan Harnad, Editor. The Behavioral and Brain Sciences, P O Bor 777 . Princeton. N. J 08540

\section{Editing}

The publishers reserve the right to edit and proof all articles and commentaries accepted for publication. Authors of articles will be given the opportunity to review the copvedited manuscript and page proofs. Commentators will be asked to review copyediting only when changes have been substantial, commentators will not see proofs. Both authors and commentators should notify the editorial office of all corrections within 48 hours or approval will be assumed.

Authors of target articles will receive $50 \mathrm{offprints} \mathrm{of} \mathrm{the} \mathrm{entire} \mathrm{treatment,} \mathrm{and}$ can purchase additional copies. Commentators will also be given an opportunity to purchase off prints of the entire treatment 


\section{The Eehavioral and Brain Sciences}

\section{To appear in Volume 4, Number 1 (1981)}

Offprints of the following forthcoming BBS treatments can be purchased in quantity for educational purposes if they are ordered well in advance. For ordering information, please write to Journals Department, Cambridge University Press, 32 East 57th Street, New York, N. Y. 10022

\begin{abstract}
Hemispheric laterality in animals and the effects of early experience

Victor H. Denenberg, University of Connecticut

A review of research with chicks, songbirds, rodents, and nonhuman primates indicates that the brain is lateralized for a number of behavioral functions. These findings can be understood in terms of three hypothetical brain processes: hemispheric activation, interhemispheric inhibition, and interhemispheric coupling. It is predicted that functional lateralization, when present, will be similar across species: the left hemisphere will tend to be involved in communicative functions while the right hemisphere will respond to spatial and affective information; both hemispheres will often interact via activation-inhibition mechanisms when affective or emotional processes are involved. Homologous brain areas and their connecting callosal fibers must remain intact throughout development for lateralization to reach its maximum level. On the basis of the finding that in rats early experience can induce laterality or facilitate its development in an already biased brain, it is hypothesized that one major function of early experience is to provide stimulation during development, which acts to enhance the growth and development of the corpus callosum.
\end{abstract}

With Commentary from M. C. Corballis, G. Ettlinger, C. E. Giurgea, L. Goldstein \& J. Nelsen, R. A. W. Lehman, R. Puccetti, D. N. Robinson, T. E. Robinson \& J. B. Becker, J. M. Warren, and others.

The case for mental duality: Evidence from split-brain data and other considerations

Roland Puccetti, Dalhousie University

The hypothesis that dual consciousness is characteristic of brain organization has been rejected, if not refuted, by almost every neuroscientist and philosopher of the mind who has bothered to consider it. Principal objections have been that it is counterintuitive and based on an arbitrary notion of what constitutes the basis of mind or person. This paper attempts to meet those objections, gives an evolutionary rationale for double consciousness in the normal brain, and invokes evidence from two kinds of visual defects that seems inexplicable on any other theory

With Commentary from R. M. Anderson, Jr. \& J. F Gonsalves, J. E. Bogen, J. L. Bradshaw, J W. Brown, P. S Churchland, J C. Eccles. M. S. Gazzaniga \& J. E. LeDoux, N. Geschwind, M. B. Green, C. E Marks, D. N. Robinson, E. A. Weinstein, K. V. Wilkes, and others
The nature of hemispheric specialization in man

J. L. Bradshaw and N. C. Nettleton, Monash University

The traditional verbal/nonverbal dichotomy is inadequate to completely describe cerebral lateralization. Nor does there seem to be a specialist processor for the encodedness of speech in the left, or for dealing with faces in the right; rather, both functions may stem from hemispheric differences in terms of analytic/holistic modes of processing, with other distinctions (e.g., focal/diffuse and serial/ parallel) being special cases of this. More fundamentally, sensory discriminations and motor control of aspects of temporal order. sequencing and rhythm characterize left hemisphere processing, and more purely spatial function characterizes the right, there being a continuum of function between the hemispheres rather than a true dichotomy

With Commentary from H. H. Brownell \& H. Gardner, C, Cohen, W. E. Cooper. J. C. Marshall, W F. McKeever, M. J. Morgan, F Nottebohm. R. Puccetti, M. Studdert-Kennedy, and others.

\section{Contrasting approaches to a theory of learning}

Timothy D. Johnston, North Carolina Division of Mental Health

Current opinion in the study of animal learning is divided between two groups those who advance the "general process" view that ecological differences among species do not affect the generality of learning principles, and those who argue that "biological boundaries" on learning severely limit the generality of such principles Although the latter approach has provided several important criticisms of the general process view, it has only limited potential as an alternative to that view. An ecological approach to the study of learning is proposed that grounds its analyses in descriptions of what it is that animals normally learn. The ecological approach expressly advocates a search for general principles of learning, while not assuming the existence of general processes; it thus offers a powerful alternative to current approaches to the study of learning

With Commentary from P. Bateson. W R. Charlesworth, M. T Ghiselin, R. A. Hinde. J Kruse \& E. Reed, J L \& R Lachman, L. Petrinovich, H ( : Plotkin \& F J Odling-Smee, H Rachlin, B Schwartz, and others

\section{Among the articles to appear in forthcoming issues of BBS:}

M. T. Ghiselin, "Categories, life, and thinking"

H. C. Plotkin \& F. J. Odling-Smee, "A multiple-level model of evolution and its implications for sociobiology

R. M. Warren, "Measurement of sensory intensity"

L. J. Cohen, "Can human irrationality be experimentally demonstrated?"

C. H. Vanderwolf \& T. E. Robinson, "Reticulo-cortical activity and behavior: A critique of the arousal theory and a new sunthesis"

H. Rachlin, R. Battalio, J. Kagel, \& L. Green, "Maximization theory in behavioral psychology"

Cambridge University Press

The Pitt Building, Trumpington Street, Cambridge CB2 IRP

32 East 57 Street, New York, N.Y. 10022

296 Beaconsfield Parade, Middle Park, Melbourne 3206
Printed in the United States of America by Science Press, Ephrata, Pennsylvania

(c) Cambridge University Press 1980 